

Case Rep Nephrol Dial 2016;6:14-20

DOI: $10.1159 / 000443727$

Publishea onine: January 15, 2016

C) 2016 The Author(s)

Published by S. Karger AG, Basel

2296-9705/16/0061-0014\$39.50/0

www.karger.com/cnd

This article is licensed under the Creative Commons Attribution-NonCommercial 4.0 International License (CC BY-NC) (http://www.karger.com/Services/OpenAccessLicense). Usage and distribution for commercial purposes requires written permission.

\title{
Nephrotic Syndrome without Hematuria due to Infection-Related Glomerulonephritis Mimicking Minimal-Change Disease in a Child
}

\author{
Yoichi Iwafuchi ${ }^{a}$ Tetsuo Morioka ${ }^{b}$ Takashi Morita $^{c}$ Kanako Watanabe ${ }^{d}$ \\ Yuko Oyama $^{\text {a }}$ Ichiei Narita $^{\mathrm{e}}$ \\ ${ }^{a}$ Department of Internal Medicine, Koseiren Sanjo General Hospital, Sanjo, Departments of \\ ${ }^{b}$ Internal Medicine, Kidney Center and ${ }^{\mathrm{C}}$ Pathology, Shinrakuen Hospital, ${ }^{\mathrm{d}}$ Division of \\ Laboratory Science, Niigata University Graduate School of Health Sciences, and ${ }^{e}$ Division \\ of Clinical Nephrology and Rheumatology, Niigata University Graduate School of Medical \\ and Dental Sciences, Niigata, Japan
}

\section{Key Words}

Nephrotic syndrome $\cdot$ Infection-related glomerulonephritis $\cdot$ Endocapillary proliferative glomerulonephritis · Minimal-change disease $\cdot$ Corticosteroids

\begin{abstract}
Nephrotic syndrome without hematuria due to infection-related glomerulonephritis is uncommon. The present report describes a case of nephrotic syndrome due to infection-related glomerulonephritis without hematuria and hypertension in an older child. A 14-year-old boy was referred to our hospital because of a 5-day history of fever, nausea, weight gain and recent leg edema without hypertension. Laboratory data showed nephrotic-range proteinuria, hypoalbuminemia, mild hypocomplementemia and acute renal injury without hematuria. Although, due to the clinical presentation, minimal-change nephrotic syndrome was mostly suspected, a renal biopsy showed endocapillary hypercellularity mainly of mononuclear cells with segmental mesangiolytic changes. Fine granular IgG and C3 deposits were noted by an immunofluorescent study; many relatively small electron-dense deposits were observed electron-microscopically. These findings led to the diagnosis of nephrotic syndrome due to infection-related endocapillary proliferative glomerulonephritis, although the causative organism of his nephritis was not detected. He recovered with rest and dietary cure. When we examine an acute nephrotic child, infection-related glomerulonephritis should be considered as the differential diagnosis to avoid unnecessary use of corticosteroids.
\end{abstract}

\section{KARGER}

Dr. Yoichi Iwafuchi

Department of Internal Medicine, Sanjo General Hospital

Tsukanome, 5-1-62

Sanjo 955055 (Japan)

E-Mail iwafuchiy@hotmail.com 


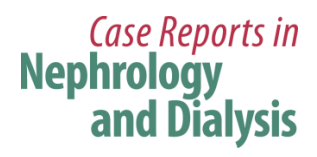

\begin{tabular}{l|l}
\hline Case Rep Nephrol Dial 2016;6:14-20 \\
\hline DOI: 10.1159/000443727 & $\begin{array}{l}\text { ○ 2016 The Author(s). Published by S. Karger AG, Basel } \\
\text { www.karger.com/cnd }\end{array}$ \\
\hline
\end{tabular}

Iwafuchi et al.: Nephrotic Syndrome without Hematuria due to Infection-Related Glomerulonephritis Mimicking Minimal-Change Disease in a Child

\section{Introduction}

Nephrotic syndrome (NS) is a minimal-change disease (MCD) in about $90 \%$ of children younger than 10 years and in about $50-70 \%$ of older children. Occasionally, however, NS is induced by self-limited renal diseases, such as infection-related glomerulonephritis (IRGN). IRGN is usually characterized by hematuria, proteinuria, edema, and often by hypertension and a mild degree of acute renal injury. When these characteristic findings are not present, misdiagnosis may be made without histological study. Here, we report a rare case of NS due to IRGN without hematuria and hypertension.

\section{Case Report}

A 14-year-old boy was referred to our hospital because of a 5-day history of low-grade fever, nausea, weight gain and recent leg edema. He had been in his usual health until approximately 1 week before admission and had no symptoms suggestive of upper respiratory or skin infection. He had not taken any drugs recently. Six months before admission, his urinalysis on school examination was normal. On admission, his blood pressure was 118/66 $\mathrm{mm} \mathrm{Hg}$, his pulse $66 / \mathrm{min}$, and his temperature $36.7^{\circ} \mathrm{C}$. He weighed $63 \mathrm{~kg}$ and had experienced $7 \mathrm{~kg}$ of weight gain in the preceding week. He was neither pale nor icteric. Physical examination on the chest and abdomen was unremarkable. He exhibited edema in his face and pitting edema in both legs. No lymphadenopathy and skin lesions were observed.

Urinary protein was $10.0 \mathrm{~g} /$ day. The urinary sediment showed $1-4$ erythrocytes and 59 leukocytes per high-power field. The selectivity index was 0.05 . The hematocrit was $41.6 \%$, hemoglobin concentration $15.1 \mathrm{~g} / \mathrm{dl}$, platelet count $248,000 / \mathrm{mm}^{3}$, and leukocyte count $8,860 / \mathrm{mm}^{3}$. The serum urea nitrogen level was $10.1 \mathrm{mg} / \mathrm{dl}$, the creatinine level 1.03 $\mathrm{mg} / \mathrm{dl}$, uric acid $4.5 \mathrm{mg} / \mathrm{dl}$, total cholesterol $199 \mathrm{mg} / \mathrm{dl}$, total protein $5.2 \mathrm{~g} / \mathrm{dl}$, and albumin $2.4 \mathrm{~g} / \mathrm{dl}$. The fractional excretion of sodium was $0.8 \%$. The C-reactive protein level was 0.22 $\mathrm{mg} / \mathrm{dl}$, IgG $985 \mathrm{mg} / \mathrm{dl}$ (normal range: 870-1,700), IgA $134 \mathrm{mg} / \mathrm{dl}$ (80-140), and IgM 116 $\mathrm{mg} / \mathrm{dl}$ (34-220). The total complement level was $27.0 \mathrm{IU} / \mathrm{l}(30-45), \mathrm{C} 391 \mathrm{mg} / \mathrm{dl}(80-140)$, C4 $9.5 \mathrm{mg} / \mathrm{dl}(11-30)$, and C1q $<1.5 \mu \mathrm{g} / \mathrm{ml}$. Antistreptolysin 0 was $164 \mathrm{IU} / \mathrm{l}(<166)$. Hepatitis $B$ virus surface antigen, hepatitis $C$ virus antibody, human immunodeficiency virus antibody, antinuclear antibody, anti-neutrophil cytoplasmic antibodies, and cryoglobulin were all negative. All other laboratory tests were within normal limits. Urine was sterile, and the throat swab cultures yielded no specific pathogens. A chest X-ray and an electrocardiogram were normal. Renal ultrasound and computed tomography showed normal kidneys.

\section{Renal Biopsy}

On the 2nd hospital day, kidney biopsy was performed to investigate the cause of NS. The patient's renal biopsy showed mild endocapillary hypercellularity, mainly of mononuclear cells, with several neutrophilic leukocytes (fig. 1a). Mitotic figures of endothelial cells rather than mesangial cells were found (fig. 1b). Mesangial matrix was not increased and segmental mesangiolytic changes were observed (fig. 1c). Mitotic figures and several apoptotic changes of the tubular epithelial cells were observed (fig. 1d, e). Mild cellular infiltrations around blood vessels, which were not clear enough to be conclusively diagnosed as vasculitis, were observed, but arteriosclerosis was not found. By immunofluorescent study, prominent fine granular IgG $(2+)$ and weakly positive $\mathrm{C} 3(1+)$ deposits were found along the capillary walls and in the mesangium (fig. 2), but IgA, IgM, C4, and C1q deposits were very modest in the same pattern. Electron-microscopically, many relatively small subepithelial 


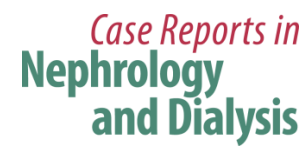

Iwafuchi et al.: Nephrotic Syndrome without Hematuria due to Infection-Related Glomerulonephritis Mimicking Minimal-Change Disease in a Child

hump-like electron-dense deposits were observed. A few subendothelial, intramembranous and mesangial deposits were also observed (fig. 3). Electron-microscopic findings were roughly compatible with the early phase of post-streptococcal acute glomerulonephritis (PSAGN).

\section{Clinical Course}

From the clinical and histopathological findings, the diagnosis of NS due to infectionrelated endocapillary proliferative glomerulonephritis (EnGN) was made, and we observed the patient with just rest and dietary cure. On the 11th hospital day, serum complement levels and renal function returned to normal: the total complement level was $43 \mathrm{IU} / \mathrm{ml}, \mathrm{C} 3134$ $\mathrm{mg} / \mathrm{dl}, \mathrm{C} 420.9 \mathrm{mg} / \mathrm{dl}$, and the serum creatinine level was $0.71 \mathrm{mg} / \mathrm{dl}$. On the 14th hospital day, his edema subsided and his proteinuria decreased to $1.0 \mathrm{~g} /$ day. On the 20th hospital day, he was discharged without any subjective symptoms.

To find the causative organism of his renal lesion, we carried out additional examinations. The levels of antibodies to the following pathogens were measured: parvovirus B19 (B19), herpes simplex virus, varicella zoster virus, parainfluenza virus, coxsackievirus A and $\mathrm{B}$, cytomegalovirus, measles virus, rubella virus, mumps virus, and Epstein-Barr virus, as well as fecal adenovirus antigen, which has been reported as the other responsible organism of post-infectious glomerulonephritis (PIGN). However, no causative organisms were identified. Nasal swabs for influenza type A and B, and serum antibody to Mycoplasma and Legionella were negative. We investigated his serum using human parechovirus and enterovirus polymerase chain reaction primer sets, which could detect human parechovirus and enterovirus (including poliovirus, coxsackievirus $\mathrm{A}$ and $\mathrm{B}$, echovirus, and rhinovirus). However, no parechovirus and enteroviral RNA sequences were identified. Immunofluorescence staining of the renal biopsy tissues with anti-B19, anti-antigen nephritis-associated plasmin receptor antibody and anti-streptococcal pyrogenic exotoxin $B$ were all negative. From the above findings, we could not detect the causative organism of his nephritis.

We observed the patient in our outpatient clinics. His mild proteinuria gradually decreased and improved over approximately the next 4 months. After 2 years, he was free from proteinuria or any symptoms.

\section{Discussion}

Based on the abrupt onset of nephrotic-range proteinuria, mild hypocomplementemia, its benign clinical course, and renal pathological findings, our patient was diagnosed as having NS due to IRGN. The diagnostic criteria for IRGN are: (1) clinical or laboratory evidence of infection preceding or at the onset of glomerulonephritis; (2) depressed serum complement; (3) endocapillary proliferation and exudative glomerulonephritis; (4) C3-dominant or co-dominant glomerular immunofluorescence staining, and (5) hump-shaped subepithelial deposits on electron microscopy [1]. At least three of the above criteria were required for the diagnosis of IRGN, and our patient almost fulfilled the criteria. Although histological findings of the present case showed diffuse EnGN, the clinical characteristic findings of IRGN, such as hematuria, obvious low serum complement level and hypertension, were not recognized. We could not detect the causative organism of his IRGN from the laboratory and renal histopathological findings.

The nomenclature for glomerulonephritis associated with infections has become confusing. In a recent study, Glassock et al. [2] proposed a nomenclature for glomerulonephritis associated with infections, which were classified into two, PIGN and IRGN. Our patient exhib- 


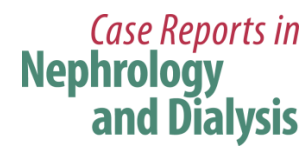

Iwafuchi et al: Nephrotic Syndrome without Hematuria due to Infection-Related Glomerulonephritis Mimicking Minimal-Change Disease in a Child

ited some clinical findings, such as fever, weight gain and leg edema, simultaneously, and there was no latent period. Such a clinical course suggested that our patient had IRGN, which was directly related to the infection itself, but without any evidence of an ongoing infection. Another possibility must be considered, i.e., that the causative agent could directly damage the kidney tissue, followed by immunocomplex-type glomerulonephritis, as suggested in parvovirus B19 IRGN [3]. Increased mitosis is usually interpreted as a repair process of tissue injury.

NS is among the most common types of kidney diseases seen in children. The proportion of EnGN to the whole of NS is very small. In Japan, EnGN is reported to be recognized in only $0.5 \%$ of primary glomerular disease except IgA nephropathy [4].

In addition, NS due to PSAGN is uncommon, occurring in approximately $0.4 \%$ of patients [5]. PSAGN is the major disease among glomerulonephritis associated with infections, and the most typical histopathological finding is EnGN [6]. In the case of PSAGN, sudden onset of edema together with gross hematuria and hypertension is a common finding and correlates with volume expansion due to sodium and fluid retention. Alternative complementary pathways are activated in PSAGN; more than $90 \%$ of patients with PSAGN have low levels of total complement and C3, and normal or mildly depressed C4 levels [7].

Our patient exhibited abrupt onset of edema, normal anti-antistreptolysin 0 titer, hypoalbuminemia and high-selectivity proteinuria, but no hematuria or hypertension. All these features were rather those of MCD. Our patient was a 14-year-old nephrotic boy with mild renal dysfunction and mild hypocomplementemia. These abnormalities were minor; however, renal biopsy was performed to determine the accurate treatment plan. From the renal histopathological findings, we diagnosed him as having EnGN. However, without renal histopathological examination, our patient could have been diagnosed with corticosteroidsensitive NS.

Glomerulonephritis associated with infection is commonly triggered by streptococci, although many other organisms, including bacterial, viral, parasitic, rickettsial and fungal infections, can also cause the condition $[8,9]$. In spite of the detailed examinations, we could not determine the causative organism of his nephritis.

Acute glomerulonephritis associated with several viral infections, such as B19, hepatitis A virus, measles, yellow fever and Epstein-Barr virus, was reported [8, 9]. In such cases, extrarenal specific symptoms associated with viruses (such as rash, liver injuries, lymph adenopathy, and arthralgia) were present. However, our patient showed no extrarenal findings.

Recently, various renal findings associated with B19 infection have been reported. Acute nephritic syndrome with hypocomplementemia often following a prodrome of fever, rash, and arthritis is common, and nephrotic-range proteinuria is seen as well [10]. Using renal histology, immune complex-mediated acute EnGN is often detected [3,11]. In this patient, hypercellularity composed of mainly mononuclear cells and a few neutrophils, mesangiolytic changes, and mitosis of endothelial cell were observed. Such findings resemble those of IRGN following B19 infection [3], although from the laboratory and renal immunohistopathological findings, B19 infections were not probable. Using frozen serum, we examined human parechovirus, which could cause injury of endothelial cells [12] as well as B19; however, its preceding infection was not proven. Some cases of abrupt onset of NS and acute cytomegalovirus infection have been reported. Renal biopsies in these cases showed findings consistent with collapsing nephropathy [13]. Recently, several cases of IgA-dominant acute PIGN were reported [14]. In our patient, the immunofluorescence pattern was obviously IgG dominant, and it was different from IgA-dominant PIGN. Electron-microscopical findings of electrondense deposits were also different. We speculate that another unrecognized pathogen, perhaps a virus, could cause NS due to IRGN. Hence, the accumulation of further cases is needed. 


\section{Case Reports in \\ Nephrology and Dialysis}

\begin{tabular}{l|l}
\hline Case Rep Nephrol Dial 2016;6:14-20 \\
\hline DOI: 10.1159/000443727 & $\begin{array}{l}\text { ○ 2016 The Author(s). Published by S. Karger AG, Basel } \\
\text { www.karger.com/cnd }\end{array}$ \\
\hline
\end{tabular}

Iwafuchi et al.: Nephrotic Syndrome without Hematuria due to Infection-Related Glomerulonephritis Mimicking Minimal-Change Disease in a Child

Boyer et al. [15] studied 201 children who were diagnosed with idiopathic NS. Of those patients, 95 were corticosteroid-sensitive and were not biopsied. Therefore, it may not be completely denied that cases who have self-limited renal diseases received corticosteroid therapy. Corticosteroids have well-recognized and potentially serious adverse effects such as poor growth, obesity, hypertension, diabetes mellitus, osteoporosis and behavioral disturbances, especially in childhood. As shown here, in childhood, NS could be induced by IRGN, and clinical and laboratory findings may resemble those of MCD. When an acute nephrotic child shows atypical clinical or laboratory findings, such as very transient hypocomplementemia, acute renal injury, and so on, IRGN should be considered as the differential diagnosis.

\section{Acknowledgment}

The authors are grateful to Mr. N. Sakamoto, Ms. S. Tsuchida, Ms. M. Yoshinuma, and Ms. M. Igashima (Department of Pathology, Shinrakuen Hospital) for their technical assistance.

\section{Statement of Ethics}

The authors have no ethical conflicts to disclose.

\section{Disclosure Statement}

There are neither conflicts of interest nor financial support to declare.

\section{References}

1 Nasr SH, Radhakrishnan J, D'Agati VD: Bacterial infection-related glomerulonephritis in adults. Kidney Int 2013;83:792-803.

-2 Glassock RJ, Alvarado A, Prosek J, et al: Staphylococcus-related glomerulonephritis and poststreptococcal glomerulonephritis: why defining 'post' is important in understanding and treating infection-related glomerulonephritis. Am J Kidney Dis 2015;65:826-832.

-3 Iwafuchi Y, Morita T, Kamimura A, et al: Acute endocapillary proliferative glomerulonephritis associated with human parvovirus B19 infection. Clin Nephrol 2002;57:246-250.

4 Sugiyama H, Yokoyama H, Sato H, et al: Renal Biopsy Registry and Japan Kidney Disease Registry: committee report for 2009 and 2010. Clin Exp Nephrol 2013;17:155-173.

5 Tasic V: Postinfectious glomerulonephritis; in Geary DF, Schaefer F (eds): Comprehensive Pediatric Nephrology. Philadelphia, Mosby Elsevier, 2008, pp 309-317.

6 Rodriguez-Iturbe B, Musser JM: The current state of poststreptococcal glomerulonephritis. J Am Soc Nephrol 2008;19:1855-1864.

7 Sulyok E: Acute proliferative glomerulonephritis; in Avner ED, Harmon WE, Niaudet P (eds): Pediatric Nephrology, ed 5. Philadelphia, Lippincott Williams and Wilkins, 2004, pp 601-613.

8 Lai SH, Lai KN: Viral nephropathy. Nat Clin Pract Nephrol 2006;2:254-262.

-9 Kanjanabuch T, Kittikowit W, Elam-Ong S: An update on acute postinfectious glomerulonephritis worldwide. Nat Rev Nephrol 2009;5:259-269.

10 Waldman M, Jeffrey B, Kopp JB: Parvovirus B19 and the kidney. Clin J Am Soc Nephrol 2007;2:S47-S56.

11 Ohtomo Y, Kawamura R, Kaneko K, et al: Nephrotic syndrome associated with human parvovirus B19 infection. Pediatr Nephrol 2003;18:280-282.

-12 O’Regan S, Robitaille P, Mongeau JG, et al: The hemolytic uremic syndrome associated with ECHO 22 infection. Clin Pediatr 1980;19:125-127.

13 Vanya G, Meghana RG, Maria VD, et al: Cytomegalovirus-induced collapsing focal segmental glomerulosclerosis. Clin Kidney J 2013;6:71-73. 
Case Reports in

Nephrology and Dialysis

\begin{tabular}{l|l}
\hline Case Rep Nephrol Dial 2016;6:14-20 \\
\hline DOI: 10.1159/000443727 & $\begin{array}{l}\text { ○ 2016 The Author(s). Published by S. Karger AG, Basel } \\
\text { www.karger.com/cnd }\end{array}$ \\
\hline
\end{tabular}

Iwafuchi et al.: Nephrotic Syndrome without Hematuria due to Infection-Related Glomerulonephritis Mimicking Minimal-Change Disease in a Child

14 Nasr SH, Markowitz GS, Whelan JD, et al: IgA-dominant acute poststaphylococcal glomerulonephritis complicating diabetic nephropathy. Hum Pathol 2003;34:1235-1241.

15 Boyer 0, Moulder JK, Somers MJ: Focal and segmental glomerulosclerosis in children: a longitudinal assessment. Pediatr Nephrol 2007;22:1159-1166.
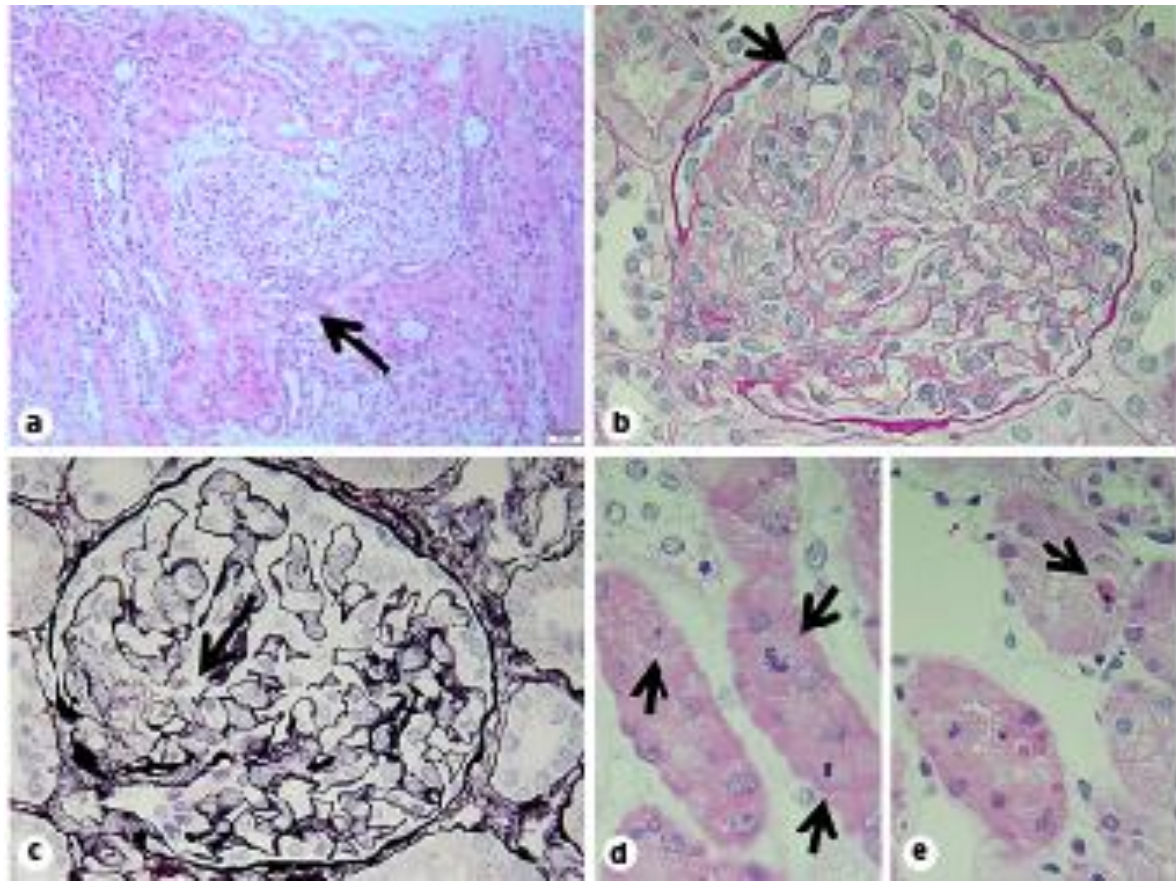

Fig. 1. a Glomeruli are mildly hypercellular. Occasional mild cellular infiltration is noted near the vas afferens (arrow). Hematoxylin and eosin stain, original magnification $\times 200$. $\mathbf{b}$ A representative glomerulus shows mild to moderate endocapillary hypercellularity, mainly mononuclear cells. A mitotic figure of apparent endothelial cell is observed (arrow). Periodic acid-Schiff stain, original magnification $\times 400$. c The same glomerulus as in $\mathbf{b}$. Mesangial matrix is not increased and segmental mesangiolysis (arrow) is noted. Periodic acid-methenamine-silver stain, original magnification $\times 400$. $\mathbf{d}$ Mitotic figures of the tubular epithelial cells (arrows) were observed. Hematoxylin and eosin stain, original magnification $\times 400$. e An apoptotic body (arrow) was also observed in a tubule. Hematoxylin and eosin stain, original magnification $\times 400$. 


\section{Case Reports in \\ Nephrology \\ and Dialysis}

\begin{tabular}{l|l}
\hline Case Rep Nephrol Dial 2016;6:14-20 \\
\hline DOI: 10.1159/000443727 & $\begin{array}{l}\text { ○ 2016 The Author(s). Published by S. Karger AG, Basel } \\
\text { www.karger.com/cnd }\end{array}$ \\
\hline
\end{tabular}

Iwafuchi et al.: Nephrotic Syndrome without Hematuria due to Infection-Related Glomerulonephritis Mimicking Minimal-Change Disease in a Child
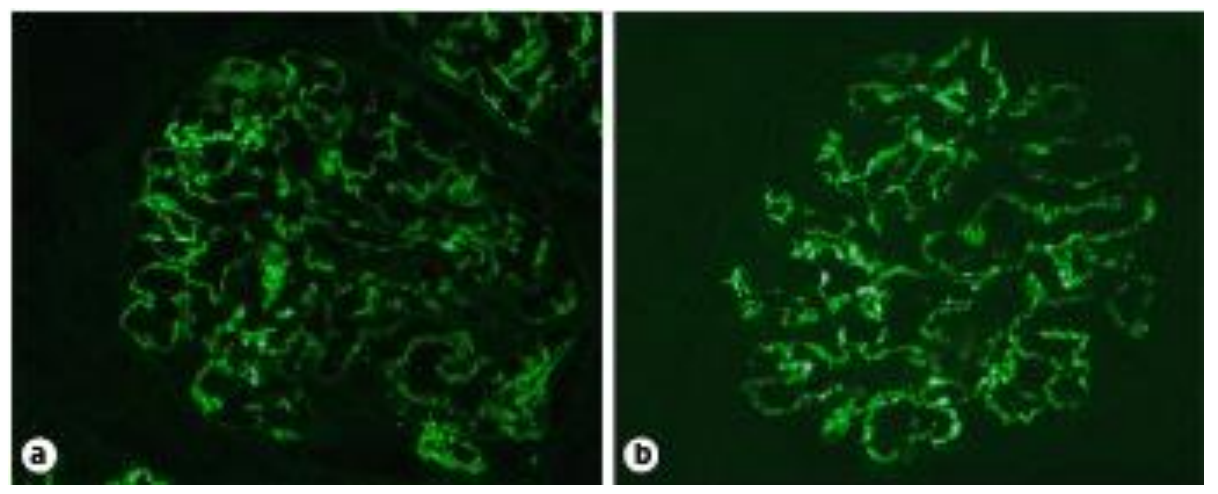

Fig. 2. By a immunofluorescent study, IgG (a) and C3 (b) depositions were seen mainly along the capillary walls and less in the mesangium.

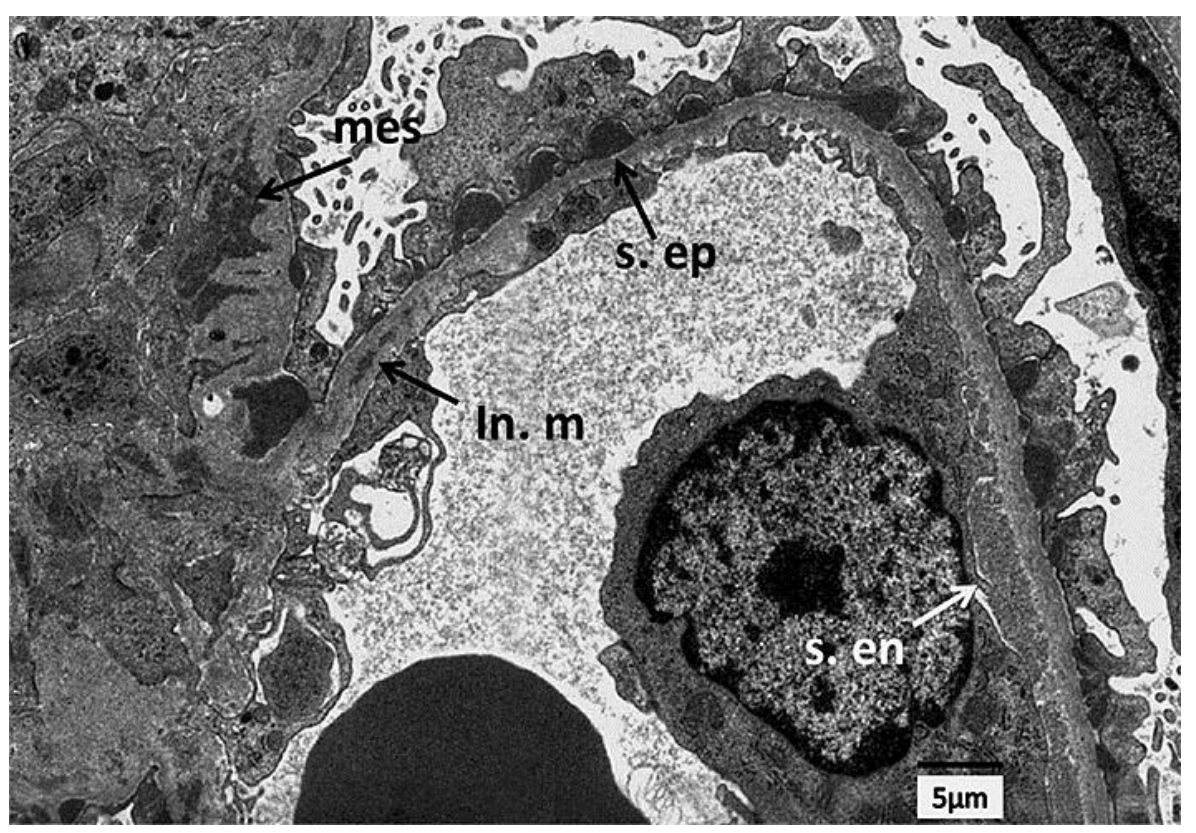

Fig. 3. There were many relatively small subepithelial electron-dense deposits without spikes (s. ep); most of them were separated from the lamina densa by the lamina rara; a few subendothelial (s. en), intramembranous (In. m) and mesangial deposits (mes) were also observed. 